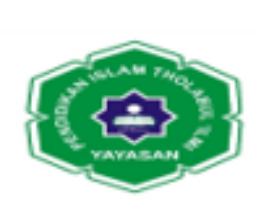

Jurnal Ilmiah METADATA

\title{
SUATU TINJAUAN HUKUM TENTANG BAGI HASIL ATAS TANAH PERTANIAN ANTARA PEMILIK TANAH DENGAN PETANI
}

\author{
Danial Syah \\ Universitas Islam Sumatera Utara \\ Email : sh.mhdanialsyah@yahoo.com
}

\begin{abstract}
ABSTRAK
Perjanjian bagi hasil pertanian merupakan salah satu sarana tolong menolong bagi sesama manusia dalam memenuhi kebutuhan hidupnya. Bagi hasil pertanian adalah suatu ikatan atau perjanjian kerja sama antara pemilik lahan dengan petani sebagai penggarap. Upah dari penggarapan lahan tersebut diambil atau diberikan dari hasil pertanian yang diusahakan, setelah selesai panen atau sesuai dengan perjanjian yang telah disepakati ketika pertama kali mengadakan transaksi.

Dalam penulisan penelitian ini penulis menggunakan metode telaah pustaka (library research) untuk mentelaah data-data sekunder yang berkaitan dengan permasalahan dalam penelitian ini dan penelitian lapangan.

Bagi hasil pertanian adalah suatu ikatan atau perjanjian kerjasama antara pemilik lahan dengan petani sebagai penggarap. Pelaksanaan bagi hasil pertanian yang dilakukan oleh masyarakat desa Dalu X Kabupaten Deli Serdang. Alasan masyarakat melakukan bagi hasil pertanian tersebut adalah antara pihak petani penggarap dan pihak pemilik lahan intinya adalah sama atau mereka saling membutuhkan.
\end{abstract}

Berdasarkan permasalahan yang dikemukakan, maka ditarik kesimpulan bahwa Sistem perjanjian bagi hasil pertanian antara petani dengan pemilik tanah di desa Dalu X Kabupaten Deli Serdang bahwa memang benar paroan tanaman karet ini dapat mengentaskan kemiskinan secara individu, tetapi secara perlahan-lahan akan dapat pula mengentaskan kemiskinan secara umum, dengan kata lain perlahan-perlahan perekonomian masyarakat tersebut menuju kea rah tingkat kehidupan yang semakin baik. Dalam hal terjadinya perselisihan atau silang sengketa antara petani dengan pemilik tanah, maka perselisihan tersebut akan diselesaikan secara musyawarah. Jika dengan musyawarah tidak tercapai kata sepakat atau dengan kata lain perselisihan tersebut belum dapat diatasi, maka perselisihan itu akan diselesaikan melalui Pengadilan. Berdasarkan kesimpulan di atas, maka disarankan agar dalam hubungan antara pihak petani dengan pemilik tanah untuk mencegah terjadinya perselisihan maka para pihak harus menjalankan kewajiban masing-masing. Dalam membuat perjanjian bagi hasil petanian dibuat dihadapan atau diketahui pihak yang mewakili kepentingan semua pihak sehingga terhindar penindasan antara pihak yang melakukan perjanjian bagi hasil tersebut.

Kata Kunci : Tinjauan Hukum, Bagi Hasil Atas Tanah Pertanian

\section{PENDAHULUAN}




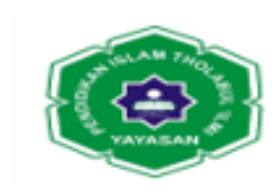

\section{Jurnal Ilmiah METADATA}

Perjanjian bagi hasil pertanian merupakan salah satu sarana tolong menolong bagi sesama manusia dalam memenuhi kebutuhan hidupnya. Bagi hasil pertanian adalah suatu ikatan atau perjanjian kerja sama antara pemilik lahan dengan petani sebagai penggarap. Upah dari penggarapan lahan tersebut diambil atau diberikan dari hasil pertanian yang diusahakan, setelah selesai panen atau sesuai dengan perjanjian yang telah disepakati ketika pertama kali mengadakan transaksi.

Bagi hasil merupakan salah satu sarana tolong menolong bagi sesama manusia dalam memenuhi kebutuhan hidupnya. Pihak yang mempunyai lahan menyerahkan lahanya kepada pihak petani atau penggarap untuk diusahakan sebagai lahan yang menghasilkan, sehingga pihak pemilik lahan dapat menikmati dari hasil lahanya, dan petani yang sebelumnya tidak memiliki lahan untuk bercocok tanam juga dapat berusaha serta dapat memperoleh hasil yang sama dari lahan tersebut.

Bagi hasil pertanian adalah suatu ikatan atau perjanjian kerjasama antara pemilik lahan dengan petani sebagai penggarap. Pelaksanaan bagi hasil pertanian yang dilakukan oleh masyarakat di Kabupaten Deli Serdang sudah berlangsung sekitar tahun 60-an. Alasan masyarakat melakukan bagi hasil pertanian tersebut adalah antara pihak petani penggarap dan pihak pemilik lahan intinya adalah sama atau mereka saling membutuhkan.

Perjanjian bagi hasil pertanian yang dilakukan oleh masyarakat di Kabupaten Deli Serdang ini sudah berlangsung cukup lama. Hal ini terjadi karena saling membutuhkan antara pemilik lahan dan dengan para petani, yang pada umumnya tidak memiliki tanah untuk digarap sebagai lahan pertanian untuk menanam karet. Para pemilik lahan yang sebelum masih berupa lahan kosong (hutan belantara), mereka tidak mampu untuk menggarapnya sendiri, karena alasan hutan belantara itu tidak dimanfaatkan, maka mereka meminta petani untuk membuka lahan itu sebagai ladang, kemudian ditanami karet dengan perjanjian hasilnya dibagi dua. Karena itu petani penggarap mau menerima tawaran kerjasama paroan tanaman karet tersebut. 


\section{Jurnal Ilmiah METADATA}

Pelaksanaan paroan tanaman pertanian di di Kabupaten Deli Serdang pada umumnya dilakukan secara tradisional, atau berdasarkan kekeluargaan dan kepercayaan. Masyarakat desa sangat menjunjung tinggi kepercayaan kata-kata yang telah diucapkan, oleh karena itu tidak pernah ingkari dari perjanjian sekalipun merasa rugi. Sudah menjadi keharusan bahwa setiap melakukan paroan tanaman pertanian ditentukan batas waktu pembagianya. Penentuan batas waktu pembagian itu ditetapkan antara pemilik lahan dengan petani penggarap. Dalam menentukan waktu pembagianya diperhatikan umur dari tanaman yang ditanam.

Pembagian hasil tanaman pada umumnya ketika tanaman tersebut sudah dapat diketahui bahwa tanaman tersebut tumbuh baik atau kecil kemungkinan akan mati atau rusak. Jika terjadi kerusakan sebelum tanaman dibagi yang bertanggung jawab adalah petani. Bentuk tanggung jawab yang bebankan kepadanya adalah menanam kembali tanaman yang rusak atau menggantinya dengan yang baru.

Sedangkan apabila setelah terjadi pembagian tanaman, terjadi kerusakan pada bagian pemilik lahan maka yang bertanggung jawab adalah pemilik lahan itu sendiri. Sebab sejak terjadi pembagian tanaman, maka sejak saat itu masingmasing bertanggung jawab terhadap hak miliknya.

\section{METODE PENELITIAN}

Penelitian ini tergolong sebagai penelitian hukum normatif. Data penelitian ini bersumber dari data sekunder yang bersumber dari bahan-bahan hukum, yang terdiri dari bahan hukum primer, sekunder dan tersier. Penelitian ini menggunakan pendekatan undang-undang dan pendekatan konseptual. Analisis data dalam penelitian ini menggunakan analisis data kualitatif.

\section{HASIL DAN PEMBAHASAN}

\section{A. Pengertian Perjanjian Bagi Hasil}

Sudikno Mertokusumo mengatakan bahwa perjanjian adalah "hubungan antara dua pihak atau lebih berdasarkan kata sepakat untuk menimbulkan 


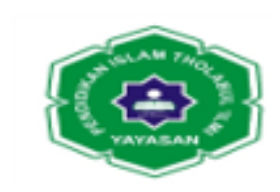

\section{Jurnal Ilmiah METADATA}

hukum". ${ }^{3}$ M. Yahya Harahap mengatakan perjanjian adalah "hubungan hukum kekayaan/harta benda antara dua orang atau lebih, yang memberi kekuatan hak pada satu pihak untuk memperoleh prestasi dan sekaligus mewajibkan pada pihak lain untuk menunaikan prestasi". 4

R. Wirjono Prodjodikoro mengatakan perjanjian adalah "suatu perhubungan hukum mengenai harta benda kekayaan antara dua pihak, dalam mana satu pihak berjanji atau dianggap berjanji untuk melakukan suatu hal atau untuk tidak melakukan sesuatu hal, sedang pihak lain berhak menuntut pelaksanaan janji itu". ${ }^{5}$

Perjanjian itu memiliki arti yang luas dan arti sempit. Arti sempit dari perjanjian hanya ditujukan kepada hubungan hukum dalam lapangan harta kekayaan saja sebagaimana dimaksud dalam Buku III KUH Perdata.

Sudikno Mertokusumo menjelaskan :

Perbedaan perbuatan hukum dan hubungan hukum yang melahirkan konsep perjanjian sebagai berikut : bahwa perbuatan hukum (rechtshandeling) yang selama ini di maksudkan dalam pengertian perjanjian adalah satu perbuatan hukum bersisi dua (een tweezijdigerechtshandeling) yakni perbuatan penawaran (aanbod) dan penerimaan (aanvaarding) . berbeda halnya kalau perjanjian dikatakan sebagai dua perbuatan hukum yang masing-masing berisi satu (twee eenzijdige rechtshandeling) yakni penawaran dan penerimaan yang didasarkan kepada kata sepakat antara dua orang yang saling berhubungan untuk menimbulkan akibat hukum, maka konsep perjanjian yang demikian merupakan suatu hubungan hukum (rechtsverhoudingen). 6

Sehubungan dengan perkembangan pengertian perjanjian tersebut, Purwahid Patrik menyimpulkan bahwa "perjanjiian dapat di rumuskan sebagai hubungan hukum antara dua pihak dimana masing-masing melakukan perbuatan hukum sepihak, penawaran dan penawaran". ${ }^{7}$

Dalam perjanjian itu sendiri terdapat 3 (unsur), yang menurut Sudikno J. Satrio adalah:

\footnotetext{
${ }^{3}$ Sudikno Mertokusumo, Mengenai Hukum, Liberty, Yogyakarta, 2000, h. 97.

${ }^{4}$ M. Yahya Harahap, Segi-Segi Hukum Perjanjian, Alumni, Bandung, 2002. h. 6

${ }^{5}$ R. Wirjono Prodjodikoro, Hukum Perdata Tentang Persetujuan-Persetujuan Tertentu, Sumur, Bandung, 2002, h. 11.

${ }^{6}$ Sudikno Mertokusumo, Op.Cit, h. 7-8.

7 Purwahd Patrik, Pembahasan Perkembangan Hukum Perjanjian, Fakultas Hukum UGM, Yogyakarta, 2000, h.15.
} 


\section{(ㄷ)}

\section{Jurnal Ilmiah METADATA}

1. Unsur essensialia;

2. Unsur naturalia;

3. Unsur accidentalia. ${ }^{8}$

Dalam perjanjian terdapat beberapa asas yaitu :

a. Asas kebebasan berkontrak

Terdapat dalam Pasal 1338 ayat (1) KUH. Perdata yang menentukan bahwa semua perjanjian yang dibuat secara sah berlaku sebagai undangundang bagi mereka yang membuatnya. Undang-und ang memperbolehkan membuat perjanjian berupa dan berisi apa saja dan perjanjian itu akan mengikat mereka yang membuatnya. Tujuan dari pembuat undang-undang menuangkan kebebasan berkontrak dalam bentuk formal, sebagai suatu asas dalam hukum perjanjian adalah untuk menghindari terjadinya kekosongan hukum dilapangan hukum perjanjian.

b. Asas Pacta Sunt Servanda.

Asas ini merupakan asas yang berhubungan dengan mengikatnya suatu perjanjian. Perjanjian yang dibuat secara sah oleh para pihak adalah mengikat bagi mereka yang membuatnya sendiri seperti undang-undang, kedua belah pihak terikat oleh kesepakatan dalam perjanjian yang mereka buat.

c. Asas Konsensualisme

Suatu perjanjian cukup adanya kata sepakat dari mereka yang membuat perjanjian itu tanpa diikuti dengan perbuatan hukum yang lain.

d. Asas Itikad Baik

Menurut Pasal 1338 ayat (3) KUH. Perdata, semua perjanjian itu harus dilaksanakan dengan itikad baik.

e. Asas Kekuatan Berlakunya Suatu Perjanjian

Pada prinsipnya semua perjanjian itu hanya berlaku bagi para pihak yang membuatnya saja, tidak ada pengaruhnya bagi pihak ketiga, diatur dalam Pasal 1315 dan Pasal 1340 KUH. Perdata.

f. Asas Kepercayaan

Seseorang mengadakan perjanjian dengan pihak lain menumbuhkan kepercayaan diantara kedua belah pihak itu bahwa satu sama lain akan memegang janjinya atau memenuhi prestasinya.

g. Asas Persamaan Hukum

Asas ini menempatkan para pihak dalam persamaan derajat, tidak ada perbedaan, sehingga para pihak wajib menghormati satu sama lain.

h. Asas Keseimbangan

Asas ini merupakan kelanjutan dari asas persamaan yang menghendaki kedua belah pihak memenuhi dan melaksanakan perjanjian itu.

i. Asas Kepastian Hukum

\footnotetext{
${ }^{8}$ J. Satrio, Hukum Perjanjian, Citra Aditya Bakti, Bandung:, 2002, h. 57.
} 


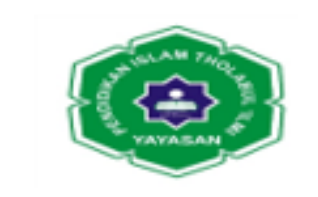

\section{Jurnal Ilmiah METADATA}

Kepastian ini terungkap dari kekuatan mengikat perjanjian itu yaitu sebagai und ang-undang bagi para pihak.

j. Asas Moral

Terdapat dalam Pasal 1339 KUH. Perdata, dalam asas ini terdapat faktorfaktor yang memberikan motivasi pada yang bersangkutan melakukan perbuatan hukum berdasarkan pada moral-moral

k. Asas Kebiasaan

Asas ini terdapat dalam Pasal 1347 KUH. Perdata, suatu perjanjian tidak hanya mengikat untuk apa yang secara tegas diatur akan tetapi juga hal-hal yang dalam keadaan dan kebiasaan yang lazim diikuti. ${ }^{9}$

\section{B. Syarat Sahnya Perjanjian Bagi Hasil}

Untuk sahnya suatu perjanjian maka Pasal 1320 KUHPerdata menentukan 4 (empat) syarat yang harus dipenuhi yaitu :

1. Sepakat mereka yang mengikatkan diri.

2. Cakap untuk membuat suatu perjanjian;

3. Mengenai suatu hal tertentu

4. Suatu sebab yang halal.

Dua syarat yang pertama (nomor 1 dan 2) dinamakan syarat-syarat subjektif, karena mengenai orang-orangnya atau subjeknya yang mengadakan perjanjian. Sedangkan dua syarat yang terakhir (nomor 3 dan 4) dinamakan syarat-syarat objektif karena mengenai isi perjanjiannya sendiri atau objeknya dari perbuatan hukum yang dilakukan itu.

Dengan sepakat atau juga dinamakan perizinan dimaksudkan bahwa kedua subjek yang mengadakan perjanjian itu harus bersepakat, setuju atau seiasekata mengenai hal-hal pokok dari perjanjian yang diadakan itu. Apapun yang dikehendaki oleh pihak yang satu, juga dikehendaki oleh pihak yang lain. Mereka menghendaki sesuatu yang sama secara timbal balik, si penjual menginginkan sejumlah uang, sedangkan si pembeli menginginkan sesuatu barang dari sipenjual. ${ }^{12}$

Ketidak cakapan seorang perempuan yang bersuami dalam Kitab Undangundang Hukum Perdata, ada hubungan dengan sistem yang dianut dalam hukum Perdata Barat (Negeri Belanda) yang menyerahkan kepemimpinan dalam keluarga itu kepada sang suami. Kekuasaan suami sebagai

${ }^{9}$ Mariam Darus Badrulzaman., KUH.Perdata Hukum Perikatan Dengan Penjelasannya, Alumni, Bandung, 2003, h.41

${ }^{12}$ R. Subekti., Aneka Perjanjian, PT. Intermasa, Jakarta, 2007, h. 17. 


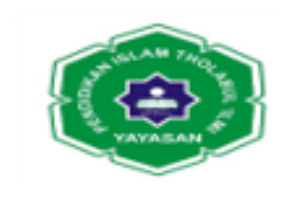

\section{Jurnal Ilmiah METADATA}

pimpinan keluarga, dinamakan maritale macht. Oleh karena ketentuan tentang ketidak cakapan seorang perempuan yang bersuami itu di Negeri Belanda sendiri sudah dicabut karena dianggap tidak sesuai lagi dengan kemajuan jaman, maka sebaiknya ketentuan tersebut di Indonesia juga dihapuskan. Dan memang dalam praktek para notaris sekarang sudah mulai mengizinkan seorang isteri, yang tunduk kepada Hukum Perdata Barat membuat suatu perjanjian dihadapannya, tanpa bantuan suaminya. Juga dari surat edaran Mahkamah Agung No. 3 tahun 1963 tanggal 4 Agustus 1963 kepada Ketua Pengadilan Negeri dan Pengadilan Tinggi di seluruh Indonesia ternyata, bahwa Mahkamah Agung menganggap pasalpasal 108 dan pasal 110 Kitab Undang-undang Hukum Perdata tentang wewenang seorang isteri untuk melakukan perbuatan hukum dan untuk menghadap didepan pengadilan tanpa izin atau bantuan dari suaminya, sudah tidak berlaku lagi. ${ }^{13}$

\section{Wanprestasi Dalam Perjanjian Bagi Hasil}

Menurut pendapat M. Yahya Harahap dalam bukunya segi-segi Hukum Perjanjian, yang dimaksud dengan wanprestsi adalah : "Pelaksanaan kewajiban yang tidak tepat pada waktunya atau dilakukan tidak menurut selayaknya". ${ }^{10}$

Peringatan tersebut dapat dinyatakan pernyataan lalai yang diberikan oleh pihak kreditur kepada pihak debitur. Pernyataan lalai oleh Mariam Darus Badrulzaman, memperinci pernyataan lalai tersebut dalam beberapa bentuk pernyataan lalai tersebut dalam beberapa bentuk pernyataan lalai yaitu :

1. Berbentuk surat perintah atau akta lain yang sejenis.

2. Berdasarkan kekuatan perjanjian itu sendiri. Apabila dalam surat perjanjian telah ditetapkan ketentuan : debitur dianggap bersalah jika satu kali saja dia melewati batas waktu yang diperjanjikan. Hal ini dimaksudkan untuk mendorong debitur untuk tepat waktu dalam melaksanakan kewajiban dan sekaligus juga menghindari proses dan prosedur atas adanya wanprestasi dalam jangka waktu yang panjang. Dengan adanya penegasan seperti ini dalam perjanjian, tanpa tegoran kelalaian dengan sendirinya pihak debitur sudah dapat dinyatakan lalai, bila ia tidak menempati waktu dan pelaksanaan prestasi sebagaimana mestinya.

3. Jika tegoran kelalaian sudah dilakukan barulah menyusul peringatan (aanmaning) dan biasa juga disebut dengan Sommasi. Dalam sommasi

\footnotetext{
${ }^{13}$ Ibid. h. 19.

${ }^{10}$ M. Yahya Harahap, Op.Cit, h. 60
} 


\section{Jurnal Ilmiah METADATA}

inilah pihak kreditur menyatakan segala haknya atas penuntutan prestasi kepada pihak debitur. ${ }^{12}$

Wanprestasi seorang debitur dapat berupa empat macam kategori yaitu sebagai berikut :

1. Tidak melakukan apa yang disanggupi akan dilakukannya.

2. Melaksanakan apa yang diperjanjikannya, tetapi tidak sebagaimana yang diperjanjikan.

3. Melakukan apa yang diperjanjikan akan tetapi terlambat.

4. Melakukan sesuatu yang menurut perjanjian tidak boleh untuk dilakukan. ${ }^{13}$

Debitur yang oleh pihak kreditur dituduh lalai, dapat mengajukan pembelaan diri atas tuduhan tersebut. Adapun pembelaan debitur yang dituduh dapat didasarkan atas tiga alasan yaitu :

1. Mengajukan tuntutan adanya keadaan yang memaksa

2. Mengajukan bahwa si kreditur sendiri juga wanprestasi

3. Mengajukan bahwa kreditur telah melepaskan haknya untuk menuntut ganti rugi. ${ }^{14}$

\section{Berakhirnya Perjanjian}

Mengenai peraturan tentang berakhirnya perjanjian diatur di dalam Bab XII Buku III KUH.Perdata. Peraturan untuk itu adalah perlu bagi kedua belah pihak, baik untuk menentukan sikap selanjutnya maupun untuk memperjelas sampai dimana batas perjanjian tersebut.

Di dalam Pasal 1381 KUH.Perdata disebutkan beberapa cara hapusnya suatu perjanjian yaitu :

1. Pembayaran

2. Penawaran tunai disertai dengan penitipan

3. Pembaharuan hutang

\footnotetext{
${ }^{12}$ Mariam Darus Badrulzaman., Op.Cit h.41.

${ }^{13}$ R. Subekti, Aneka Perjanjian, PT. Intermasa, Jakarta, 2005, h. 45

${ }^{14}$ R.Wirjono Prodjodikoro., Op.Cit, h.52.
} 


\section{Jurnal Ilmiah METADATA}

4. Perjumpaan hutang

5. Percampuran hutang

6. Pembebasan hutang

7. Musnahnya benda yang terhutang

8. Kebatalan/pembatalan

9. Berlakunya syarat batal

10. Kadaluarsa atau lewat waktu.

\section{E. Sistem Perjanjian Bagi Hasil Pertanian Antara Petani Dengan Pemilik Tanah Di Kabupaten Deli Serdang}

Paroan atau bagi hasil pertanian adalah suatu ikatan atau perjanjian kerjasama antara pemilik lahan dengan petani sebagai penggarap. Pelaksanaan paroan tanaman karet yang dilakukan oleh masyarakat desa Daluh X Kabupaten Deli Serdang sudah berlangsung sekitar tahun 80-an. Alasan masyarakat melakukan paroan tersebut adalah antara pihak petani penggarap dan pihak pemilik lahan intinta adalah sama atau mereka saling membutuhkan.

Perjanjian paroan atau bagi hasil pertanian merupakan salah satu sarana tolong menolong bagi sesame manusia dalam memenuhi kebutuhan hidupnya. Paroan atau bagi hasil pertanian adalah suatu ikatan atau perjanjian kerja sama antara pemilik lahan dengan petani sebagai penggarap. Upah dari penggarapan lahan tersebut diambil atau diberikan dari hasil pertanian yang diusahakan, setelah selesai panen atau sesuai dengan perjanjian yang telah disepakati ketika pertama kali mengadakan transaksi.

Paroan atau bagi hasil merupakan salah satu sarana tolong menolong bagi sesama manusia dalam memenuhi kebutuhan hidupnya. Pihak yang mempunyai lahan menyerahkan lahanya kepada pihak petani atau penggarap untuk diusahakan sebagai lahan yang menghasilkan, sehingga pihak pemilik lahan dapat menikmati dari hasil lahanya, dan petani yang sebelumnya tidak memiliki lahan untuk bercocok tanam juga dapat berusaha serta dapat memperoleh hasil yang sama dari lahan tersebut 


\section{당}

\section{Jurnal Ilmiah METADATA}

Praktek paroan tanaman karet yang dilakukan msayarakat desa Daluh X Kabupaten Deli Serdang sudah berlangsung sekitar tahun 80-an. Faktor atau alasan masyarakat melakukan paroan tersebut, menurut keterangan beberapa orang responden dari pihak petani penggarap dan pihak pemilik lahan intinya adalah sama (saling membutuhkan).

Paroan tanaman karet di desa Daluh X Kabupaten Deli Serdang ini sudah berlangsung cukup lama. Hal ini terjadi karena saling membutuhkan antara pemilik lahan dan dengan para petani, yang pada umumnya tidak memiliki tanah untuk digarap sebagai lahan pertanian untuk menanam karet. Para pemilik lahan yang sebelum masih berupa lahan kosong (hutan belantara), mereka tidak mampu untuk menggarapnya sendiri, karena alasan hutan belantara itu tidak dimanfaatkan, maka mereka meminta petani untuk membuka lahan itu sebagai ladang, kemudian ditanami karet dengan perjanjian hasilnya dibagi dua. Karena itu petani penggarap mau menerima tawaran kerjasama paroan tanaman karet tersebut.

Pelaksanaan paroan tanaman karet di desa Daluh X Kabupaten Deli Serdang pada umumnya dilakukan secara tradisional, atau berdasarkan kekeluargaan dan kepercayaan. Mereka lakukan tidak secara tertulis sebagaimana ketentuan hukum yang berlaku di Indonesia, yaitu mencatat atau dibuat surat perjanjian.

Masyarakat desa Daluh X Kabupaten Deli Serdang sangat menjunjung tinggi kepercayaan kata-kata yang telah diucapkan, oleh karena itu tidak pernah ingkari dari perjanjian sekalipun merasa rugi. Sudah menjadi keharusan bahwa setiap melakukan paroan tanaman karet ditentukan batas waktu pembagianya. Penentuan batas waktu pembagian itu ditetapkan antara pemilik lahan dengan petani penggarap. ${ }^{17}$

Dalam menentukan waktu pembagianya diperhatikan umur dari tanaman tanaman karet yang ditanam. Pada umumnya karet itu 6 tahun baru menghasilkan atau dapat disadap getahnya. Pembagian hasil tanaman karet pada umumnya

${ }^{17}$ Hasil Wawancara Dengan Lemanan Siregar, Kepala Desa Daluh X Kabupaten Deli Serdang Tanggal 13 Pebruari 2013 


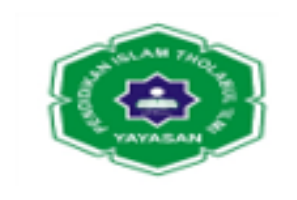

\section{Jurnal Ilmiah METADATA}

ketika telah berumur tiga tahun, karena pada umur tersebut sudah dapat diketahui bahwa karet tersebut tumbuh baik atau kecil kemungkinan akan mati atau rusak.

Jika terjadi kerusakan sebelum tanaman karet dibagi menurut responden, yang bertanggung jawab adalah petani. Bentuk tanggung jawab yang bebankan kepadanya adalah menanam kembali karet yang rusak atau menggantinya dengan yang baru. Sedangkan apabila setelah terjadi pembagian tanaman karet, terjadi kerusakan pada bagian pemilik lahan maka yang bertanggung jawab adalah pemilik lahan itu sendiri. Sebab sejak terjadi pembagian tanaman karet, maka sejak saat itu masing-masing bertanggung jawab terhadap hak miliknya. ${ }^{18}$

Di Daluh X Kabupaten Deli Serdang, sistem sewa dan sistem lainnya jarang sekali dilakukan karena umumnya penggarap tidak mempunyai modal untuk membayar sewa yang biasanya dibayar dimuka dan risiko gagal panen tidak ditanggung bersama, sehingga hanya Bagi Hasil yang paling banyak dan memungkinkan untuk dilakukan. Banyaknya praktek sistem bagi hasil ini dilakukan antara lain juga disebabkan sistem ini tidak merendahkan derajat petani penggarap, tidak mengenal istilah majikan dan buruh, pranata bagi hasil bersifat tolong menolong dan kekeluargaan, sehingga segala sesuatunya dapat diselesaikan secara musyawarah, serta bagi hasil sudah membudaya di Indonesia. Namun demikian tradisi Bagi Hasil ini akibat pengaruh perkembangan ekonomi dan keuangan, nampaknya telah bergeser dari sistem yang mengandung prinsip pemerataan ke arah kepentingan ekonomi. $^{19}$

Unsur positif bagi hasil adalah perimbangannya didasarkan atas dasar keadilan dan terjaminnya kedudukan hukum yang layak bagi penggarap dengan menegaskan hak-hak dan kewajiban, baik dari penggarap maupun pemilik. ${ }^{20}$

Menurut hasil wawancara diketahui bahwa dasar dari transaksi bagi hasil ini adalah pemilik tanah ingin memungut hasil dari tanahnya atau ingin memanfaatkan tanahnya, tapi ia tidak ingin atau tidak dapat mengerjakannya sendiri. ${ }^{21}$

18 Hasil Wawancara Dengan Lemanan Siregar, Kepala Desa Daluh X Kabupaten Deli Serdang Tanggal 13 Pebruari 2013

${ }^{19}$ Hasil Wawancara Dengan Lemanan Siregar, Kepala Desa Daluh X Kabupaten Deli Serdang Tanggal 13 Pebruari 2013

${ }^{20}$ Hasil Wawancara Dengan Lemanan Siregar, Kepala Desa Daluh X Kabupaten Deli Serdang Tanggal 13 Pebruari 2013

${ }^{21}$ Hasil Wawancara Dengan Lemanan Siregar, Kepala Desa Daluh X Kabupaten Deli Serdang Tanggal 13 Pebruari 2013 


\section{Jurnal Ilmiah METADATA}

\section{F. Penyelesaian Hukum Jika Dalam Perjanjian Bagi Hasil Antara Petani Dengan Pemilik Tanah Di Kabupaten Deli Serdang Terjadi Persengketaan}

Tujuan dari suatu perjanjian tidak lain adalah untuk ditepati atau dipenuhi oleh orang atau pihak-pihak yang mengadakannya. Memenuhi janji yang telah dibuat dan disepakati berarti pula merupakan suatu perbuatan mementingkan orang lain terhadap siapa janji itu ditujukan. Dengan demikian tidak dapat dipungkiri bahwa di dalam pergaulan hidup manusia seringkali terjadi hal yang disebut ingkar atau wanprestasi.

Prestasi dalam suatu perjanjian pada dasarnya mengandung bentuk tertentu, baik untuk memberikan sesuatu, untuk berbuat sesuatu atau untuk tidak berbuat sesuatu. Dalam pelaksanaannya tidak tertutup suatu kemungkinan bahwa prestasi tersebut tidak dapat terwujud sebagaimana yang diharapkan, maka oleh hukum selanjutnya pihak yang tidak dapat memenuhi prestasi tersebut dinyatakan lalai atau ingkar janji (wanprestasi).

Dengan adanya ingkar janji atau wanprestasi terhadap janji itulah, maka penting adanya peraturan hukum perjanjian yang didalamnya mengatur seluk beluk peristiwa sehubungan dengan orang yang ingkar janji atau wanprestasi. Ingkar janji disini adalah tidak menepati janji sebagaimana mestinya. Dengan demikian secara umum wanprestasi dapat diartikan dengan pelaksanaan prestasi atau kewajiban yang tidak sebagaimana diharapkan

Dalam setiap perjanjian selalu terkandung suatu resiko yaitu kewajiban untuk memikul kerugian jika terjadi suatu peristiwa di luar kesalahan salah satu pihak yang menimpa barang yang menjadi objek perjanjian.

Dengan demikian dalam perjanjian terdapat resiko yang harus ditanggung oleh salah satu pihak. Dalam perjanjian, tanggung jawab karena kesalahan merupakan bentuk yang lazim dalam pertanggung jawaban perdata yang didasarkan pada tiga prinsip sebagaimana disebutkan dalam Pasal 1365, 1366 dan Pasal 1367 KUH. Perdata. 


\section{당}

\section{Jurnal Ilmiah METADATA}

Dalam Pasal 1365 KUH. Perdata disebutkan bahwa tiap-tiap perbuatan melawan hukum yang membawa kerugian kepada seorang lain, mewajibkan orang yang karena salahnya menerbitkan kerugian itu, mengganti kerugian tersebut.

Lebih lanjut dalam Pasal 1366 KUH. Perdata disebutkan bahwa setiap orang bertanggung jawab tidak saja untuk kerugian yang disebabkan karena perbuatannya, tetapi juga untuk kerugian yang disebabkan karena kelalaian atau kurang hati-hati.

Sedangkan di dalam Pasal 1367 ayat (1) KUH. Perdata disebutkan bahwa seorang tidak saja bertanggung jawab untuk kerugian yang disebabkan karena perbutannya sendiri tetapi kuga untuk kerugian yang disebabkan karena perbuatan orang-orang yang menjadi tanggungannya atau disebabkan oleh barang-barang yang berada di bawah pengawasannya.

Jika Pasal-pasal tersebut di atas dihubungkan dengan perjanjian bagi hasil pertanian antara petani dengan pemilik tanah, maka dalam hal pertanggung jawaban disebabkan karena kesalahan salah satu pihak harus dibuktikan oleh pihak yang dirugikan.

Dalam perjanjian bagi hasil pertanian antara petani dengan pemilik tanah apabila salah satu pihak menderita kerugian akibat kesalahan pihak lain dalam menjalankan profesinya, maka pihak yang dirugikan dapat menuntut ganti rugi baik karena wanprestasi atau karena perbuatan melawn hukum. Jika didasarkan pada perbuatan melawan hukum, maka pihak yang dirugikan harus membukti8kan kesalahan tindakan yang bertentangan dengan kewajibannya.

Jika tuntutan ganti ruginya didasarkan pada wanprestasi, maka harus dibuktikan kerugian akibat dari tidak dipenuhinya kewajiban sesuai dengan perjanjian yang telah disepakati.

Dalam perjanjian bagi hasil pertanian antara petani dengan pemilik tanah pihak petani dinyatakan wanprestasi adalah apabila :

1. Pihak petani penggarap tidak melaksanakan apa yang disanggupi akan dilakukannya sesuai dengan isi perjanjian.

2. Melaksanakan perjanjian tetapi tidak sebagaimana mestinya. 


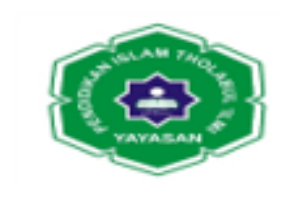

\section{Jurnal Ilmiah METADATA}

3. Melaksanakan isi perjanjian yang telah disepakati bersama tetapi terlambat. ${ }^{25}$

Dalam perjanjian bagi hasil pertanian antara petani dengan pemilik tanah, pernyataan keadaan wanprestasi ini tidak dapat terjadi dengan sendirinya, akan tetapi harus terlebih dahulu diperlukan adanya suatu pernyataan lalai yaitu suatu pesan dari pihak pemilik tanah bahwa perjanjian bagi hasil pertanian antara petani dengan pemilik tanah pada saat kapan selambatnya ia mengharapkan pemenuhan prestasi. Dari pesan ini pula selanjutnya akan ditentukan dengan pasti saat mana seseorang berada dalam keadaan wanprestasi atau ingkar janji tersebut, sehingga pihak yang menimbulkan kerugian harus pula menanggung segala akibat yang telah merugikan pihak lain.

Untuk menentukan bahwa para pihak berada dalam keadaan wanprestasi adalah apabila salah satu pihak berada dalam keadaan tertagih, dimana dengan tagihan atau teguran itu pihak tersebut harus melaksanakan prestasinya. Peneguran ataupun tagihan ini sangat erat hubungannya dengan faktor pelaksanaan perjanjian.

Jadi salah satu pihak berada dalam keadaan tertagih yang mengakibatkan baginya suatu keadaan wanprestasi adalah dengan jalan sebagai berikut :

1. Menerima surat dari pemilik tanah yang ditujukan kearah pelaksanaan perjanjian bagi hasil pertanian tersebut.

2. Menerima perintah atau surat yang ditujukan kearah pelaksanaan perjanjian bagi hasil. Teguran atau tuntutan secara resmi yaitu teguran atau tuntutan yang maksudnya bersifat penagihan yang diberikan oleh pemilik tahan yang ditujukan kepada penggarap tanah pertanian yang isinya adalah berupa perintah agar petani melaksanakan perjanjian dengan segera atau dalam tempo atau waktu yang ditentukan.

3. Dengan kekuatan perjanjian yang dibuatnya. Dalam hal ini tidak diperlukan adanya penagihan oleh pemilik tanah. Maksudnya untuk menimbulkan akibat hukum sebagaimana yang dilakukan dengan suatu surat teguran atau penagihan tidak diperlukan lagi. ${ }^{26}$

25 Hasil Wawancara Dengan Lemanan Siregar, Kepala Desa Daluh X Kabupaten Deli Serdang Tanggal 13 Pebruari 2013

${ }^{26}$ Hasil Wawancara Dengan Lemanan Siregar, Kepala Desa Daluh X Kabupaten Deli Serdang Tanggal 13 Pebruari 2013 


\section{Jurnal Ilmiah METADATA}

Sebagai akibat timbulnya kerugian salah satu pihak dalam perjanjian jual beli tersebut, maka undang-undang memberikan sesuatu hak baginya untuk menuntut diantara beberapa hal yaitu :

1. Membayar ganti rugi kepada pihak pemilik tanah.

2. Pembatalan perjanjian.

3. Peralihan resiko.

4. Membayar biaya perkara, jika permasalahan ini sampai diperkarakan di pengadilan. ${ }^{27}$

Karena wanprestasi mempunyai akibat-akibat yang sangat penting, maka harus ditetapkan lebih dahulu apakah si debitur memang benar-benar telah melakukan wanprestasi dan apabila disangkal olehnya, harus sanggup dibuktikan.

Jika petani sudah diperingatkan atau sudah dengan tegas ditagih janjinya tetapi tetap tidak melaksanakan prestasinya, maka petani berada dalam keadaan lalai atau alpa dan terhadapnya dikenakan sanksi-sanksi :

1. Membayar ganti rugi.

Ganti rugi terdiri dari tiga unsur yaitu biaya, rugi dan bunga. Yang dimaksud dengan biaya adalah segala pengeluaran atau ongkos yang nyata-nyata sudah dikeluarkan oleh salah satu pihak. Sedangkan rugi adalah kerugian karena kerusakan barang-barang milik pemilik tanah yang diakibatkan oleh kelalaian petani. Bunga adalah kerugian yang berupa kehilangan keuntungan yang sudah dibayangkan atau dihitung oleh pemilik tanah.

Menurut hasil wawancara disebutkan bahwa ganti rugi terdiri dari dua faktor yaitu :

1. Kerugian yang nyata-nyata diderita

2. Keuntungan yang seharusnya diperoleh

Kedua faktor tersebut dicakup dalam pengertian, biaya, kerugian dan bunga. Biaya adalah pengeluaran-pengeluaran nyata, misalnya biaya Notaris, biaya perjalanan dan seterusnya. Kerugian adalah berkurangnya kekayaan kreditur sebagai akibat dari pada ingkar janji dan bunga adalah keuntungan yang seharusnya diperoleh kreditur jika tidak terjadi ingkar janji. ${ }^{28}$

${ }^{27}$ Hasil Wawancara Dengan Lemanan Siregar, Kepala Desa Daluh X Kabupaten Deli Serdang Tanggal 13 Pebruari 2013

${ }^{28}$ Hasil Wawancara Dengan Lemanan Siregar, Kepala Desa Daluh X Kabupaten Deli Serdang Tanggal 13 Pebruari 2013 


\section{Jurnal Ilmiah METADATA}

"Dalam perjanjian bagi hasil pertanian antara petani dengan pemilik tanah ditentukan bahwa dalam hal terlambatnya salah satu pihak untuk melaksanakan kewajibannya sesuai dengan ketentuan dan dalam jadwal waktu yang telah ditentukan adalah merupakan salah satu bentuk dari wanprestasi”. ${ }^{29}$ Penentuan wanprestasi ini sendiri erat kaitannya dengan suatu pernyataan lalai yaitu suatu pesan dari salah satu pihak untuk memberitahukan pada saat kapan selambatnya ia mengharapkan pemenuhan prestasi.

Dengan demikian sebagai hal yang tidak dapat dipisahkan dalam penentuan pernyataan wanprestasinya pihak adalah ketentuan batas pelaksanaan perjanjian bagi hasil itu sendiri.

Keterlambatan melakukan kewajiban ini dapat juga terjadi dari bentuk wanprestasi lainnya, seperti halnya melaksanakan sesuatu yang tidak sesuai dengan apa yang telah diperjanjikan. Sementara bentuk wanprestasi ini juga harus dapat dibedakan terhadap lalainya pihak kedua untuk tidak melakukan kewajibannya sama sekali, karena dalam hal demikian pihak kedua tidak dapat dianggap terlambat memenuhi pelaksanaan prestasi.

Dalam perjanjian bagi hasil pertanian antara petani dengan pemilik tanah, maka jika timbul kerugian di salah satu pihak, maka pihak yang menimbulkan kerugian harus bertanggung jawab untuk memberikan ganti rugi kepada pihak yang dirugikan. Adapun dasar hukum yang dipakai dalam tanggung jawab adalah Pasal 1367 KUH. Perdata yang menyebutkan bahwa seseorang bertanggung jawab juga untuk kerugian yang disebabkan karena perbuatan orang-orang yang menjadi tanggungannya atau disebabkan oleh barang-barang yang berada di bawah pengawasannya.

Dalam setiap pekerjaan pasti mempunyai risiko yaitu kewajiban untuk memikul kerugian jika ada suatu kejadian di luar kesalahan salah satu pihak yang menimpa benda yang dimaksudkan dalam perjanjian. Dengan demikian risiko

${ }^{29}$ Hasil Wawancara Dengan Lemanan Siregar, Kepala Desa Daluh X Kabupaten Deli Serdang Tanggal 13 Pebruari 2013 


\section{Jurnal Ilmiah METADATA}

adalah untuk menentukan siapa yang harus menanggung kerugian apabila pembeli tidak memenuhi prestasi di luar kesalahan.

Dalam perjanjian bagi hasil pertanian antara petani dengan pemilik tanah, jika wanprestasi karena kesalahan salah satu pihak, maka ganti rugi sudah pasti akan ditanggung oleh pihak yang menimbulkan kerugian. Tetapi akan lain halnya jika tidak dipenuhinya sesuatu prestasi karena di luar kesalahan para pihak yang dalam hal ini berarti terjadi sesuatu peristiwa secara mendadak yang tidak dapat diduga-duga terlebih dahulu dan karena itu tidak dapat dipertanggung jawabkan kepada pihak yang menderita kerugian. ${ }^{30}$

Dengan demikian kerugian yang dapat dimintakan penggantian itu tidak hanya yang berupa biaya-biaya yang sungguh-sungguh telah dikeluarkan atau kerugian yang sungguh-sungguh menimpa pemilik tanah tetapi juga yang berupa kehilangan keuntungan yaitu keuntungan yang akan didapat jika petani tidak lalai.

Tidak semua kerugian dapat dimintakan penggantian. Undang-Undang mengadakan pembatasan mengenai apa yang boleh dituntut sebagai ganti rugi yaitu dengan menetapkan hanya kerugian yang dapat dikira-kira atau diduga pada waktu perjanjian dibuat dan yang sungguh-sungguh dapat dianggap sebagai suatu akibat langsung dari kelalaian si berhutang saja dapat dimintakan penggantian.

Dalam hal terjadinya keadaan atau kejadian overmacht atau keadaan memaksa di luar kemampuan manusia dan hal-hal lain yang berada diluar kekuasaan yang wajar pihak bersangkutan dan terjadi secara mendadak, tidak disengaja dan tidak terduga, seperti gempa bencana alam, kebakaran, huru hara, epidemi (wabah penyakit), perang, perang saudara dan peraturan pemerintah yang kesemuanya langsung berhubungan dengan perjanjian ini, maka sesuai dengan perjanjian maka masing-masing pihak dibebaskan dari kewajiban atau pelaksanaan kewajibannya.

Salah satu pengecualian hukuman terhadap tindakan yang dilakukan untuk memberikan ganti rugi adalah apabila terjadi suatu keadaan memaksa (force majeur). Keadaan memaksa (force majeur) adalah suatu keadaan yang dapat

${ }^{30}$ Hasil Wawancara Dengan Lemanan Siregar, Kepala Desa Daluh X Kabupaten Deli Serdang Tanggal 13 Pebruari 2013 


\section{Jurnal Ilmiah METADATA}

menyebabkan bahwa suatu hak atau suatu kewajiban dalam suatu perjanjian tidak dapat dilaksanakan. ${ }^{31}$

Dengan demikian keadaan memaksa ini dapat diartikan sebagai suatu keadaan yang terjadi di luar kesalahan salah satu pihak hingga menghalangi pembeli untuk memenuhi prestasinya.

Meskipun demikian keadaan memaksa ini harus dapat dinilai hingga benar-benar dapat dipastikan bahwa secara logika atau akal sehat prestasi tersebut tidak akan mungkin terlaksana. Atau dalam hal lain bahwa prestasi masih mungkin terlaksana, namun harus diimbangi dengan suatu pengorbanan yang besar dibandingkan manfaat yang hendak dicapai.

Dalam pelaksanaan suatu perjanjian jual beli pakan udang, maka pada umumnya ditentukan tentang keadaan memaksa ini telah diberikan batasan tertentu hingga hanya terhadap keadaan yang demikian dapat disebut sebagai suatu keadaan memaksa. Penentuan ini sendiri pada dasarnya tidak bertentangan dengan asas kebebasan berperjanjian bagi hasil pertanian dalam KUH. Perdata.

Dalam perjanjian bagi hasil pertanian antara petani dengan pemilik tanah yang dimaksud dengan force majeur adalah adanya bencana alam seperti gunung meletus, angin taufan. Gempa bumi, banjir, maupun keadaan perang dan atau peraturan pemerintah dibidang moneter yang pelaksanaannya sesuai dengan peraturan pemerintah.

Jadi jelaslah bahwa keadaan memaksa (force majeur) itu adalah suatu keadaan tidak dapat dipenuhinya prestasi oleh karena terjadi suatu peristiwa bukan karena kesalahannya, sebab peristiwa tersebut tidak dapat diketahui atau tidak dapat diduga akan terjadi pada waktu membuat perjanjian.

\section{KESIMPULAN}

Sistem perjanjian bagi hasil pertanian antara petani dengan pemilik tanah di daerah Daluh X Kabupaten Deli Serdang bahwa memang benar paroan tanaman

${ }^{31}$ Hasil Wawancara Dengan Lemanan Siregar, Kepala Desa Daluh X Kabupaten Deli Serdang Tanggal 13 Pebruari 2013 


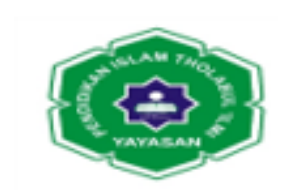

Jurnal Ilmiah METADATA

karet dilakukan dengan cara sistim bagi hasil tanaman karet tersebut dibagi dua antara pemilik tanah dengan petani/penggarap tanah. Mengenai kerusakan tanaman jika kerusakannya sebelum panen maka yang bertanggung jawab adalah petani dan jika kerusakan tanah dan tanaman sesudah panen maka kerusakannya ditanggung oleh pemilik tanah.

Dalam hal terjadinya perselisihan atau silang sengketa antara petani dengan pemilik tanah, maka perselisihan tersebut akan diselesaikan secara kekeluargaan. Jika dengan kekeluargaan tidak tercapai kata sepakat atau dengan kata lain perselisihan tersebut belum dapat diatasi, maka perselisihan itu akan diselesaikan melalui musyawarah yang disaksikan oleh para pejabat desa/kepala desa.

\section{DAFTAR PUSTAKA}

\section{A. Buku}

Abdulkadir Muhammad., Hukum Perikatan, Alumni, Bandung, 2002.

-------;Perjanjian Baku Dalam Praktek Perusahaan Perdagangan, Citra Aditya Bakti, 2002

Bambang Sunggono., Metode Penelitian Hukum, PT. Raja Grafindo Perkasa, Jakarta, 2003

J. Satrio., Hukum Perjanjian, PT.Citra Aditya Bhakti, Bandung, 2002.

Mariam Darus Badrulzaman., KUH.Perdata Hukum Perikatan Dengan Penjelasannya, Alumni, Bandung, 2003.

-------., Perjanjian Baku (Standard) Perkembangannya Di Indonesia, Alumni, Bandung, 2000

M. Yahya Harahap,., Segi-Segi Hukum Perjanjian, Alumni, Bandung, 2002.

R. Wirjono Prodjodikoro,., Hukum Perdata Tentang Persetujuan-Persetujuan Tertentu, Sumur, Bandung,2002.

R. Subekti., Aneka Perjanjian, PT. Intermasa, Jakarta, 2005

RM. Subanindyo Hadiluwih, Asas-Asas Hukum Adat, Universitas Islam Sumatera Utara, Medan, 2007. 


\section{Jurnal Ilmiah METADATA}

Salim HS, Perkembangan Hukum Kontrak Innominaat di Indonesia, Sinar Grafika, Jakarta, 2006

Soepomo, Hubungan Antara Individu dan Masyarakat Menurut Hukum Adat, Prad nya Paramita, Jakarta, 2000.

\section{B. Peraturan Perundang-Undangan}

Kitab Undang-Undang Hukum Perdata

\section{Internet}

http://www..go.id/content/view/5369/1/Bagi Hasil Pertanian, 22 Desember 2012 http://www.go.id/kompas, Perspektif Hukum Tentang Bagi Hasil, Ginandjar Kartasasmita, 22 Desember 2012. 